\title{
Effects of PLGA Nanofibre on Osteoarthritic Chondrocytes
}

(Kesan Gentian Nano PLGA ke atas Sel Kondrosit Osteoartritis)

\section{B.S.SHAMSUL, S.R. CHOWDHURY*, B.H.I. RUSZYMAH \& B.M.Y. NOR HAMDAN}

\section{ABSTRACT}

Chondrocytes obtained from osteoarthritis $(\mathrm{OA})$ joints has been recognized as an abnormal cell; however, it's proven to have potential in supporting cartilage regeneration. We have isolated chondrocytes from OA joints (OAC) and expanded chondrocytes growth medium (CGM). The growth kinetic, immunophenotyping and cell multilineage differentiation were analyzed to confirm the OAC stemness. The optimal condition to developed PLGA nanofibre with ratio 50:50 were $20 \%$ concentration of PLGA, flow rate with $0.3 \mathrm{~mL} / \mathrm{h}, 10 \mathrm{kv}$ voltage and $10 \mathrm{~cm}$ distance from nozzle to the collector. The toxicity level, scanning electron microscopy (SEM) and q-PCR analysis was performed in the present study. OAC fulfills the minimal criteria to be known to have stem cell as the cell easily adheres to the culture plate, shows high expression $(\geq 95 \%)$ for $C D 13, C D 29, C D 44, C D 73$ and $C D 90$ and less expression ( $\leq 2 \%)$ for $C D 45$ and HLA-DR and potentially induced to mesodermal multilineage, which is osteocytes, adipocytes and chondrocytes. Toxicity test showed no adverse effect of PLGA towards the cell. Based on the cell-PLGA nanofibre interaction, difference in fibre size will influence the proliferation of the cell. Nanofibres with $100 \mathrm{~nm}$ in size showed high proliferation of OAC and better gene and protein expression compared to monolayer culture. Thus, we concluded that OAC has the potential to be used in cartilage regeneration based on the presence of stem cell markers as similar to the human bone marrow. The cartilage regeneration will be more efficient if OAC cultured on $3 D$ microenvironment as showed in the present study.

Keywords: Cytoskeleton; differentiation; electrospinning; osteoarthritis; tissue engineering of cartilage

\section{ABSTRAK}

Sel kondrosit yang diperoleh daripada sendi pesakit osteoartritis (OA) terbukti berpotensi untuk membantu pertumbuhan semula tulang rawan. Walau bagaimanapun, sel kondroit mempunyai kecenderungan untuk melalui proses pembezaan semasa pengkulturan, maka persekitaran tiga dimensi diperlukan untuk mengatasi masalah pembezaan tersebut. Oleh itu, sel kondrosit yang diisolasi daripada sendi $O A(O A C)$ telah dikulturkan dalam media CGM dan proses analisis seperti pertumbuhan kinetik dan pencirian sel stem dilakukan sebelum disemai ke atas gentian nano yang dihasilkan. Gentian nano PLGA dipilih berdasarkan ciri-ciri versetilnya berserta kondisi optimum kepekatan cecair, kadar aliran, voltan dan jarak dari jarum picagari ke pengumpul yang digunakan. Tahap ketoksikan, pengimbasan mikroskop elektron (SEM) dan analisis q-PCR juga telah dilakukan dalam kajian ini. Keputusan kajian menunjukkan, oAC memenuhi kriteria minimum memiliki ciri sel stem dan ia mudah berpoliferasi di atas plat kultur, ekspresi penanda sel stem yang tinggi ( $\geq 95 \%)$ untuk CD13, CD29, CD44, CD73 dan CD90 (s2\%) CD45 dan HLA-DR serta berpotensi diinduksi kepada leluhur mesoderm. Gentian nano elektrospun tidak menunjukkan kesan toksik kepada sel malah mempengaruhi proliferasi sel semasa pengkulturan. Berdasarkan interaksi gentian nano PLGA dan OAC, perbezaan saiz gentian akan mempengaruhi proliferasi sel. Gentian nano bersaiz $100 \mathrm{~nm}$ telah menunjukkan berlakunya proliferasi OAC yang lebih tinggi dan ekspresi gen dan protein yang lebih baik berbanding dengan kultur monolapisan. Kesimpulannya, OAC berpotensi sebagai sumber sel untuk penjanaan semula tulang rawan berdasarkan kepada ekspresi penanda sel stem seperti yang diekspresikan oleh sumsum tulang manusia. Penjanaan tulang rawan akan lebih berkesan jika OAC dikulturkan di atas persekitaran mikro tiga dimensi seperti yang ditunjukkan di dalam kajian ini.

Kata kunci: Elektrospun; kejuruteraan tisu tulang rawan; perbezaan; osteoartritis; sitorangka

\section{INTRODUCTION}

Tissue engineering of articular cartilage involves the process of articular chondrocytes isolation, followed by cell seeding on biocompatible matrices or scaffold, cell cultures and subsequent implantation of injured knees (Langer \& Vacanti 1993). Various scaffolds have been successfully developed using natural or synthetic polymers and extensively studied in vitro and in vivo for cartilage tissue engineering (Dimida et al. 2017; Dua et al. 2016; KhorsandGhayeni et al.2016; Wang et al. 2017). Important aspects such as the function, structure and organization need to be emphasized while constructing the scaffold for therapeutic applications. This characteristic is important for the cell attachment and modulating the cellular phenotype and functional properties. Hypothetically if a scaffold material resembles the real environment of the extracellular matrix 
(ECM), it will be able to provide a better surrounding for a cell to proliferate and response.

The microenvironment of cartilage tissue, the native environment for chondrocytes, is composed of type II collagen fiber with the diameter of 100 to $300 \mathrm{~nm}$ (Darling \& Athanasiou 2003; Yoshimoto et al. 2003). Electrospinning technique is extensively being used to develop a fibrous scaffold with nano-topography, which resembles the fibrous structure of ECM in human body. The resulting nanofibre can provide a conducive microenvironment and indirectly regulate chondrocytes natural reaction harvested from the cartilage tissue. In addition, nanofibre has a porous structure and high surface area to facilitate the oxygen and nutrients exchange (Thapa et al.2003). To date, there are numerous studies embarked on fabricating nanofibres for tissue engineering purposes from different biomaterials including poly(glycolic acid) (PGA) and poly(lactic acid) (PLA), as well as poly(lactic-co-glycolide) (PLGA) copolymers (Gentile et al. 2014; Mano et al. 2004). Through de-esterification, these polymers degrade and are removed from human body. PGA polymer is highly crystalline, hydrophilic and degrades relatively fast. Even though structurally similar to PGA, PLA exhibits dissimilar mechanical, physical and chemical properties because of a pendant methyl group on the alpha carbon. Generally, the preferred polymer for the fabrication of musculoskeletal substitute is PLGA compared with its constituent homopolymers (Gentile et al. 2014). Mechanical and degradation properties of PLGA can be control by varying PLA and PGA ratio (Félix Lanao et al. 2013). Furthermore, this polymer is FDA approved and safe for human use (clinical trials) and research purposes (Liu et al. 2010). Therefore, PLGA polymers were selected in the present study in fabricating nanofibres.

Cell sources are an important factor in tissue engineering. To date, the usage of bone marrow mesenchymal stem cells (BMSCs) are extensively tested to develop treatment for cartilage injuries (Dua et al. 2016; Nazempour \& Van Wie 2016). Various studies have reported that BMSCs potentially support the regeneration of injured cartilage (Pak et al. 2016; Ude et al. 2018). Mesenchymal stem cells from other sources such as adipose and Wharton jelly have been tested for their potential application in cartilage tissue regeneration (Koh et al. 2015; Liu et al. 2017; Pak et al. 2016). Besides, chondrocytes from the cartilage tissues has also been applied extensively for cartilage regeneration (Madeira et al. 2015). Comparative study on the chondrocytes from native and osteoarthritic cartilage tissues showed that osteoarthritic chondrocytes (OAC) demonstrate more stemness properties i.e. the presence of higher mesenchymal progenitor cells (MPCs) compared to normal chondrocytes (Alsalameh et al. 2004; Jiang \& Tuan 2015; Oda et al.2016). MPCs from mature organs have embarked into a new potential therapeutic approach for tissue repair. The isolated MPCs in mature tissues may also be used for remodeling the abnormal organ in pathologic conditions, in which these cells already activated but not well regulated into differentiated cell types. The reported paracrine mechanism properties of MPCs make them attractive for use in cartilage tissue engineering; however, many of these analyses were done in monolayer cultures. It is still uncertain whether MPCs from OAC can exert their beneficial effect on a $3 \mathrm{D}$ culture environment. Thus, the objective of this study was to evaluate the effectiveness of OAC cultured on PLGA nanofibres in cartilage tissue regeneration. OAC morphology, growth kinetics, immunophenotype activity, toxicity level and the interaction of this cell on fabricated fibers were also analyzed.

\section{MATERIALS AND METHODS}

\section{CHONDROCYTES ISOLATION AND MONOLAYER CULTURE}

With the approval of Universiti Kebangsaan Malaysia Research and Ethics Committee (UKM 1.5.3.5/244/FF2014-215), six human osteoarthritis cartilage samples were obtained as redundant tissue from consented patients after total knee replacement (TKR) surgery. Samples were diced into approximately $1.0 \mathrm{~mm}^{3}$ segments and digested using $0.6 \%(\mathrm{w} / \mathrm{v})$ collagenase type II (Worthington, USA) at $37^{\circ} \mathrm{C}$ for $6 \mathrm{~h}$. The isolated osteoarthritis chondrocytes (OAC) were then centrifuged, re-suspended in chondrocyte growth medium (CGM) and plated in 6-well-plates (Greiner, Germany) with the initial seeding of 5000 cells $/ \mathrm{cm}^{2}$. The CGM was prepared using equal volume of Ham F12 nutrient mixture and Dulbecco's modified Eagles medium (FD; Biowest, USA) and supplemented with 10\% FBS (Gibco, USA), Insulin-Transferrin-Selenium (ITS; Gibco, USA), insulin-like growth factor-1 (IGF-1; Invitrogen Inc.) and transforming growth factor- $\beta 3$ (TGF- $\beta 3$ ) (Invitrogen Inc.) as described elsewhere (Al Faqeh et al. 2012; Chua et al. 2005; Ude et al. 2014). The waste medium was replaced every 2-3 days until it reaches $70-80 \%$ confluence. Cells were trypsinized using $0.05 \%$ Trypsin-EDTA (Gibco, USA) and subcultured until passage 3 .

\section{STEM CELL MARKER ANALYSIS BY FLOW CYTOMETRY}

Osteoarthritic chondrocytes (OAC) were tested at passage 3 by flow cytometry for surface marker expression to evaluate the stem cells properties according to the International Society of Cellular Therapy (ISCT) guidelines (Dominici et al. 2006). The cells were harvested with $0.05 \%$ trypsinEDTA, washed with $0.2 \%$ bovine serum albumin (BSA) in PBS and stained with mouse anti-human CD29, CD44, CD45, CD73, CD90 anti-HLA-DR (BD Pharmingen, USA) and CD13 antibodies (Life Technology, USA). In brief, 2 $\times 10^{5}$ cells were suspended in $100 \mu \mathrm{L}$ of $0.2 \%$ BSA in PBS and stained with individual antibodies (at a concentration as per manufacturer's recommendation) in separate tubes for $30 \mathrm{~min}$. The cells were then washed with $0.2 \% \mathrm{BSA} /$ PBS twice and fixed in $4 \%$ paraformaldehyde. Samples were washed twice in PBS, suspended in $0.2 \%$ BSA/PBS and analyzed by FACS Calibur cytometer (BD Biosciences, USA) using Cell Quest Pro software. Ten thousand gated 
events were recorded. Gating was determined based on unstained controls.

\section{DIFFERENTIATION POTENTIAL ANALYSIS OF OSTEOARTHRITIC CHONDROCYTES (OAC)}

Multi-lineage differentiation potential of OAC was assayed in passage 3 by inducing their differentiation into osteocytes, adipocytes and chondrocytes. BMSCs were also induced as a control.

Osteogenic differentiation Osteogenic differentiation of $\mathrm{OAC}$ and BMSCs was induced for 21 days in FD medium (Gibco, USA) supplemented with $0.1 \mathrm{mM}$ dexamethasone (Sigma-Aldrich), $10 \mathrm{mM}$ b-glycerol phosphate (SigmaAldrich) and 0.2 mM ascorbic acid-2-phosphate (SigmaAldrich). Cultures were replenished with fresh medium every 3 days. Differentiation was assessed by staining with Alizarin red for calcium deposition. Briefly, cells were fixed with cold ethanol for $1 \mathrm{~h}$, rinsed with PBS and stained with Alizarin red for $1 \mathrm{~h}$. Excess stain was washed off using PBS, followed by incubation with boric acid buffer and counterstaining with haematoxylin. Controls and induced cells were then evaluated using a bright field microscope (Olympus-CK40, Japan).

Adipogenic differentiation Adipogenic differentiation of OAC and BMSCs was induced in FD medium (Gibco, USA) supplemented with $0.25 \mathrm{mmol} / \mathrm{L} \mathrm{3}$-isobutyl1-methylxanthine (Sigma-Aldrich), $100 \mathrm{nmol} / \mathrm{mL}$ dexamethasone and $100 \mathrm{nmol} / \mathrm{L}$ human recombinant insulin (Sigma-Aldrich). Culture medium was changed every 3 days. On day 21, cells were stained with Oil Red $\mathrm{O}$ to identify lipid deposition. Briefly, the adipogenic cultures were rinsed once with PBS and fixed with $10 \%$ formalin for $60 \mathrm{~min}$ at room temperature. Formalin was discarded and the cells were stained with $0.36 \%$ Oil Red $\mathrm{O}$ stain for $50 \mathrm{~min}$. The cells were then examined using a bright field microscope.

Chondrogenic differentiation Chondrogenic differentiation of OAC was induced in FD medium (Gibco, USA) supplemented with transforming growth factor-beta-3 (TGF-b3; $10 \mathrm{ng} / \mathrm{mL}$ ). Briefly, OAC and BMSCs were cultured in chondrogenic medium for 21 days. The resulting culture was fixed and stained with toluidine blue to identify the presence of proteoglycans using bright field microscope.

\section{CELL SEEDING ON NANOFIBRE-BASED PLGA SCAFFOLDS}

A nanofibre sheet was fabricated using electrospinning. A 20 wt. \% polymer solution was prepared by dissolving co-polymer 85:15 PLGA (123 kDa; Iv $=0.39 \mathrm{~g} / \mathrm{dl})$ and 50: 50 PLGA $(98 \mathrm{kDa}, \mathrm{Iv}=0.33 \mathrm{~g} / \mathrm{dl})$ in a 7:3 mixtures of dichloromethane (Sigma-Aldrich) and dimethylformamide (Sigma-Aldrich) (Hasmad et al. 2018). An electric field of $\pm 10 \mathrm{kV}$ was provided by a high-voltage power supply between a $23 \mathrm{G}$ needle (cathode) and a rotating collecting target (anode, cylinder type: $4 \mathrm{~cm}$ radius, $10 \mathrm{~cm}$ length).
The distance between the needle tip and the collector was $10 \mathrm{~cm}$. The PLGA solution was spun at the flow rate of $0.3 \mathrm{~mL} / \mathrm{h}$ and nanofibre was collected on round cover glass attached to the rotating drum. To synthesize PLGA nanofibres of varying diameters, a different variable on an electric field, syringe needle (cathode) and a rotating collecting target (anode, cylinder type: $4 \mathrm{~cm}$ radius, 12 $15 \mathrm{~cm}$ length) was applied. Obtained PLGA nanofibre was left overnight at room temperature for drying. The cover glasses with PLGA sheets were sterilized with $70 \%$ ethanol and were placed into tissue culture plate. Then, 100,000 cells $/ \mathrm{cm}^{2}$ OAC were seeded on the PLGA sheet for proliferation and differentiation study and cultured at $37^{\circ} \mathrm{C}$ in $5 \% \mathrm{CO} 2$ incubator.

\section{SCANNING ELECTRON MICROSCOPY (SEM)}

The PLGA nanofibre sheets were subjected to SEM observation. Briefly, the nanofibre was fixed with GA for at least $24 \mathrm{~h}$ at $4^{\circ} \mathrm{C}$ and then washed three times with 0.1 $\mathrm{M}$ sodium cacodylate solution. The samples were then post-fixed with $1 \%$ osmium tetraoxide for $2 \mathrm{~h}$ at $4^{\circ} \mathrm{C}$ and dehydrated with increasing concentration of acetone (35, 50, 75 and $95 \%$ for $10 \mathrm{~min}$ each and three changes in $100 \%$ for $15 \mathrm{~min}$ ). The dehydrated samples were transferred into specimen basket and immersed in $100 \%$ acetone and dried with critical point dryer (Baltec 030 CPD, Liechtenstein, Switzerland) for approximately 30 min. Thereafter, the samples were mounted on copper stub using double-sided carbon tape and sputter coated (Polaron E5100 sputter coater, Milan, Italy) with gold-palladium. The samples were then examined using Phenom G2 Pro Desktop scanning electron microscope (Phenom-World, Netherlands). The diameter of PLGA fibers was calculated based on the SEM images using ImageJ software 2.6.

\section{LIVE AND DEAD ASSAY}

Live and dead cell staining (Life Technologies, USA) was used to analyze the viability of OAC according to the manufacturer's instructions. Briefly, live and dead stain solution was prepared with $2 \mathrm{mM}$ calcein $\mathrm{AM}$ and $4 \mathrm{mM}$ EthD-1 in PBS as the working solution. OAC was incubated with the working solution for $30 \mathrm{~min}$. Cells were then washed with PBS and observed using A1R CLSM (Nikon).

\section{PBMC AND T CELL PROLIFERATION ASSAYS}

To test the in vitro immunogenicity, peripheral blood mononuclear cells (PBMC) and T cell proliferation assay was performed. PBMC were obtained from healthy donors in heparinized vacutainer (BD) and separated by centrifugation at $400 \mathrm{~g}$ for $30 \mathrm{~min}$ on a Ficoll-Paque density gradient. PBMC were stained with carboxy fluorescein succinimidyl ester (CFSE) as per manufacturer's instructions (BioLegends). The cells were then re-suspended in RPMI1640, containing $2 \mathrm{mM}$ L-glutamine, $100 \mathrm{U} / \mathrm{mL}$ penicillin and $100 \mu \mathrm{g} / \mathrm{mL}$ streptomycin, (Invitrogen), $1.5 \mathrm{~g} / \mathrm{L}$ sodium bicarbonate (Sigma) and $10 \%$ fetal bovine serum (Invitrogen). Cells 
were seeded at $1.0 \times 10^{6}$ cells per well in a 12 well plate in $500 \mu \mathrm{L}$ of culture medium layered with $2 \mathrm{~mm}$ discs of nanofibre scaffold. The proliferative response of PBMCs was evaluated by assessing tritiated thymidine $(3 \mathrm{H}-\mathrm{TdR}$; Perkin Elmer Boston, USA) incorporation. 3H-TdR (0.037 $\mathrm{MBq} /$ well $(0.5 \mu \mathrm{Ci} /$ well $))$ was added to wells and incubated at $37^{\circ} \mathrm{C}$ for $96 \mathrm{~h} .100 \mu \mathrm{L}$ of cell suspension was transferred to 96 well plate and exposed to a freeze/thaw cycle at $-20^{\circ} \mathrm{C}$ to lyse the cells and were harvested onto a filter mat by using an automated cell harvester (Harvester Mach III M; TOMTEC, CT, USA). Thymidine incorporation was measured with liquid scintillation spectroscopy on a beta counter (MicroBeta ${ }^{\circledR}$ TriLux; Perkin Elmer, Boston, USA) after the addition of scintillation fluid (OptiPhase Super-Mix Cocktail; Perkin Elmer, Boston, USA), and readouts were in counts per min (CPM). Cultures activated with $1 \mu \mathrm{g} / \mathrm{mL}$ polyhydroxyalkonates (PHA) was used as positive control. For $\mathrm{T}$ cell proliferation assay, remaining $400 \mu \mathrm{L}$ of cells were harvested and stained with the CD3 antibody (BD Biosciences, San Jose, CA, USA) and analyzed for CFSE intensity by flow cytometry (FACS Calibur, BD, San Jose, CA, USA). Sub-generations of CD3 positive T cells and their proliferative index were calculated using ModFit $\mathrm{LT}^{\mathrm{TM}}$ software (Verity Software House, ME, USA).

\section{IMMUNOCYTOCHEMICAL ANALYSIS}

Immunocytochemistry (ICC) staining of OAC on culture plate and nanofibres sheets was performed to examine the expression of type II collagen ( $\mathrm{Col} 2 ; 1: 300$ dilutions; Abcam, USA). Briefly, samples were fixed with $4 \%$ paraformaldehyde (Sigma-Aldrich) for $30 \mathrm{~min}$ at room temperature followed by permeabilization with $0.1 \%$ Triton X-100 (Invitrogen) in PBS for $5 \mathrm{~min}$. Cells were then incubated with $10 \%$ goat serum for $1 \mathrm{~h}$ at $37^{\circ} \mathrm{C}$ to block non-specific binding of antibodies. Subsequently, cells were incubated with primary antibodies at $4^{\circ} \mathrm{C}$ overnight, followed by washing twice with PBS and incubation with appropriate secondary antibodies (Invitrogen) at room temperature for $2 \mathrm{~h}$. Nuclei were counterstained with 0.1 $\mathrm{mg} / \mathrm{mL}$ of DAPI (Invitrogen) for $5 \mathrm{~min}$ and images were captured with a fluorescence microscope (Nikon, Japan). The cells on nanofibre sheets were then observed and evaluated using Nikon Eclipse Ti fluorescence microscope (Nikon, Japan). Images of OAC seeded on top of all scaffolds were captured at five different spot to calculate the number of attached cells. Total cell attachment was calculated using the following formula:

$$
\text { Total cell attached }=\frac{\text { Average Cell Count }}{\text { Objective area of the microscope }}
$$

\section{SULPHATED GLYCOSAMINOGLYCAN (sGAG) PRODUCTION ASSAY}

OAC on nanofibres sheets at 24,48 and $72 \mathrm{~h}$ was digested with a papain digestion solution $(125 \mu \mathrm{g} / \mathrm{mL}$ papain, $5 \mathrm{mM}$ L-cystein, $100 \mathrm{mM} \mathrm{Na}_{2} \mathrm{HPO}_{4}$ and $5 \mathrm{mM}$ EDTA; pH 6.8) at $60^{\circ} \mathrm{C}$ for $16 \mathrm{~h}$. The sulphated glycosaminoglycan (sGAG) content was analyzed using a 1,9-dimethylmethylene blue (DMMB) assay (Biocolor, UK). The DMMB was prepared and filtered according to the manufacturer's protocol. A $20 \mu \mathrm{L}$ aliquot of each sample was pipetted into the microplate reader, shaken for $5 \mathrm{~s}$ after $200 \mu \mathrm{L}$ DMMB was added to the plate. Samples were analyzed immediately by measuring the absorbance at $525 \mathrm{~nm}$.

\section{QUANTITATIVE REAL-TIME POLYMERASE CHAIN REACTION (qRT- PCR)}

Total RNA was extracted with Trizol Reagent (Gibco, USA) from OAC cultured on a culture plate, pellet form and PLGA nanofibre. Two-step qRT-PCR for chondrocytes specific genes; aggrecan (ACAN), type II and type I collagen (Col II/I), SOX 9, COMP, MMP13 and ADAMTS5 were performed using iScript ${ }^{\mathrm{TM}}$ cDNA Synthesis Kit followed by amplification using iQTM SYBR1 Green Supermix (BioRad, USA) on MyiQ ${ }^{\mathrm{TM}}$ iCycler Real-Time PCR Detection System (BioRad) as per kit instructions. Relative quantification of the gene expression was performed using the $\Delta \mathrm{Ct}$ method. Housekeeping gene glyceraldehyde phosphate dehydrogenase (GAPDH) was used for internal normalization. Primer sequences are shown in Table I.

\section{STATISTICAL ANALYSIS}

The results were expressed as mean \pm standard error of the mean (SEM) and analyzed using two-way ANOVA and followed by Tukey's multiple comparison tests. The differences were considered significant when $p<0.05$.

\section{RESULTS}

\section{MORPHOLOGY AND STEM CELL PROPERTIES OF OAC}

OAC cultured in CGM demonstrated high cells density representing high mitotic activity with small polygonal shape at passage 0 . By passage 3, OAC still retained its

TABLE 1. List of anabolic and catabolic markers

\begin{tabular}{lll}
\hline \multicolumn{1}{c}{ Gene } & \multicolumn{1}{c}{ Forward 5'-3' } & \multicolumn{1}{c}{ Reverse 5' '-3' } \\
\hline TYPE 1 COL & AAGGCTTCAAGGTCCCCCTGGTG & CAGCACCAGTAGCACCATCATTTC \\
TYPE 2 COL & GGCAATAGCAGGTTCACGTACA & CGATAACAGTCTTGCCCCACTT \\
GAPDH & GGCGATGCTGGCGCTGAGTAC & TGGTTCACACCCATGACGA \\
MMP-13 & CAAAAACGCCAGACAAATGTGACC & GATGCAGGCGCCAGAAGAATCT \\
SOX9 & CTGAGTCATTTGCAGTGTTTTCT & CATGCTTGCATTGTTTTGTGT \\
ADAMTS5 & CTTTGAAGCTGATGGCCCTAAA & AGTGGTGGTCGGAGATTCGTA \\
\hline
\end{tabular}



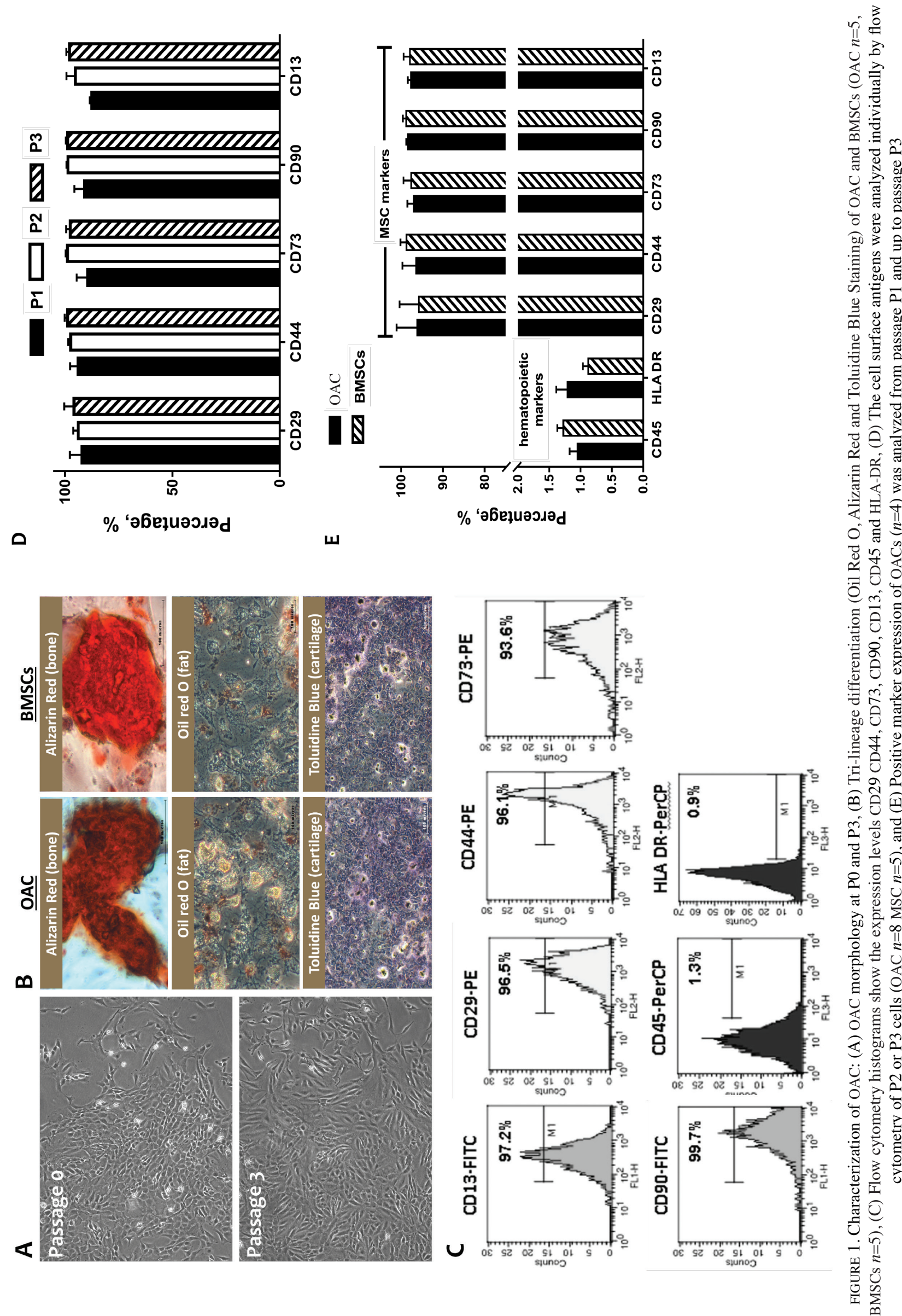
initial polygonal morphology (Figure 1(A)). Human $\mathrm{OAC}$ and BMSCs were tested for differentiation into the three main cell lineages: osteocyte, adipocyte, and chondrocyte (Figure 1(B)). OAC cultured in osteogenic medium displayed small-stratified clusters and Alizarin red staining confirmed the deposition of calcium. In adipogenic differentiation assay, lipid droplets appeared on the induced OAC and positive staining of Oil Red O confirm the lipid deposition. Chondrogenic differentiation was achieved by culturing the cells with chondrogenic medium and staining with toluidine blue demonstrates the presence of proteoglycans in the culture. The comparable multilineage differentiation potential of OAC with BMSCs confirms the presence of mesenchymal stem cells. Flow cytometry analyses showed that OAC expressed all the stem cell markers as similar to BMSCs. More than $95 \%$ of OAC at P1 expressed CD13, CD29, CD44, CD73 and CD90 less than $5 \%$ of cells expressed CD45 and the immune activation marker HLA-DR, which was similar for BMSC. The percentage of BMSCs marker expression of OAC was $>90 \%$ at subsequent passages until P3 (Figure 1(C)-1(E)).
EFFECT OF PLGA POLYMER COMPOSITION ON NANOFIBRE PROPERTIES

PLGA nanofibre scaffold was fabricated using 50:50 and 85:15 (Lactide:Glycolide) polymer. It was found that the average diameter of fiber for the scaffold of 50:50 PLGA was $89 \pm 28 \mathrm{~nm}$, ranging from 60 to $120 \mathrm{~nm}$ (Figure 2(A)). Whereas, the fiber diameter for the scaffold of 85:15 PLGA scaffold was $143 \pm 24 \mathrm{~nm}$ ranging from 120 to $170 \mathrm{~nm}$ (Figure 2(B)). Subsequently, these scaffolds were used to evaluate the attachment and growth properties of OAC. As shown in Figure 2(C), pre-incubation of the scaffold with culture medium prior to cell seeding resulted in the enhancement of cellular attachment. However, significantly higher attachment of OAC was observed only on preconditioned PLGA 50:50 scaffolds $(4318 \pm 412.1$ cells/ $\mathrm{mm}^{2}$ ). The adherent cell number in pre-conditioned PLGA 50:50 was also significantly higher compared to that in pre-conditioned PLGA 85:15 (2689 \pm 398.3 cells $\left./ \mathrm{mm}^{2}\right)$. To understand the growth properties, the number of OAC was measured at 24, 48 and $72 \mathrm{~h}$. The cells number increases exponentially with culture time for both PLGA scaffolds. At $72 \mathrm{~h}$, cells number was significantly higher in PLGA
A
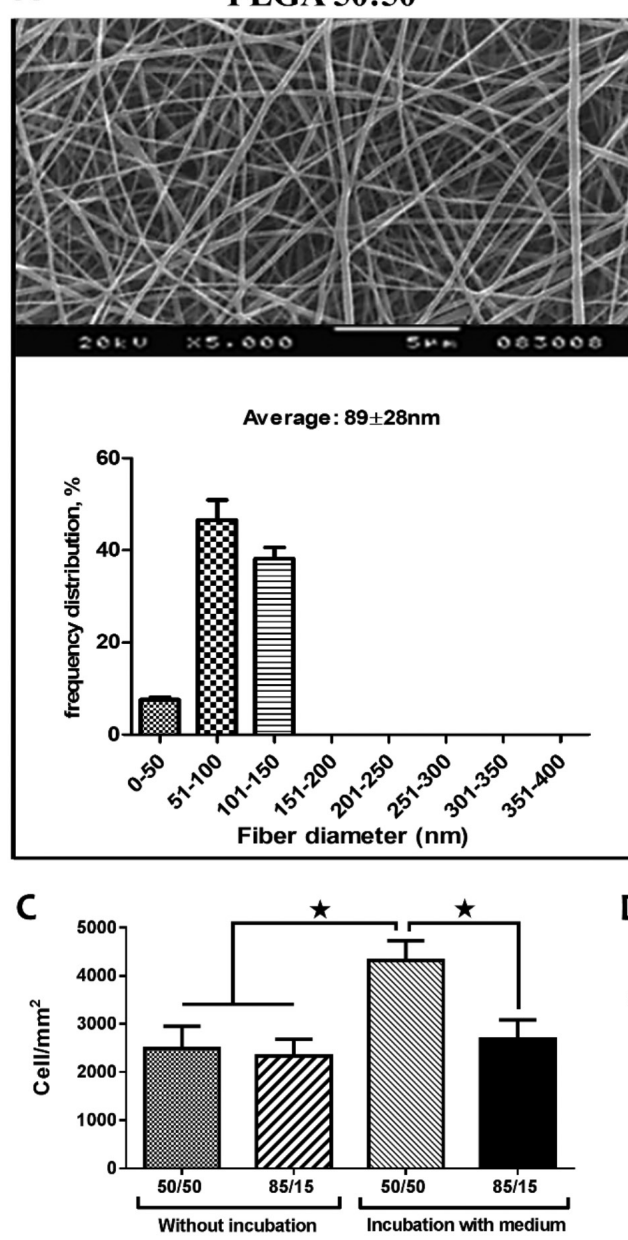

B

PLGA 85:15
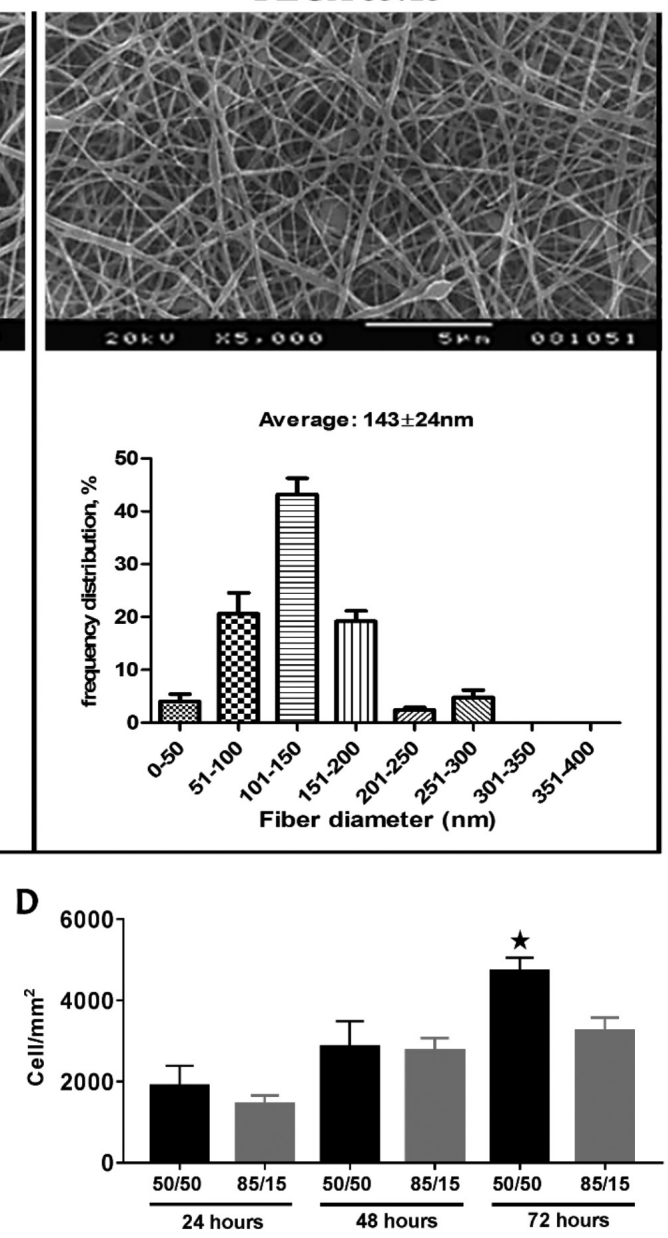

FIGURE 2. SEM images of fiber diameter and viability of OAC after cultured on the PLGA nanofibres: (A-B) SEM images with a different range of fiber diameter, (C) Pre-incubation of the scaffold with or without culture medium, and (D) Growth properties of OAC was measured at 24, 48 and 72 h. ${ }^{*} p<0.05$; significant different 
50:50 scaffolds $\left(4725 \pm 162.9\right.$ cells $\left./ \mathrm{mm}^{2}\right)$ compared to PLGA 85:15 scaffold (Figure 2(D)). Considering all the results, subsequent study was performed using PLGA 50:50 scaffold only.

\section{EFFECT OF FIBER DIAMETER ON OAC GROWTH PROPERTIES}

Fiber diameter is one of the important factor that regulate cellular behavior in culture, thus, PLGA nanofibre scaffolds of different diameter were fabricated by manipulating the independent variables (voltage, distance and size of the needle) and physical properties of the solutions. Three different scaffolds were fabricated with the diameter of $89 \pm 28 \mathrm{~nm}, 255 \pm 64 \mathrm{~nm}$ and $443 \pm 83 \mathrm{~nm}$ (Figure 3(A)3(C)). Subsequently, OAC was seeded on all 3 scaffolds, and viability of cells was evaluated using live and dead assay (Figure 3(D)). It was found that increase in fiber diameter significantly reduced the number of viable cells. The number of live cells on plain surface $(806.8 \pm 124)$ and PLGA scaffold with fiber diameter of $89 \pm 28 \mathrm{~nm}(847$ \pm 51.32 cells $/ \mathrm{mm}^{2}$ ) was comparable and the values were significantly higher than that on PLGA scaffold with fiber diameter of $255 \pm 64 \mathrm{~nm}\left(640.6 \pm 59.97 \mathrm{cells} / \mathrm{mm}^{2}\right)$ and $443 \pm 83 \mathrm{~nm}\left(511.4 \pm 75.2\right.$ cells $\left./ \mathrm{mm}^{2}\right)($ Figure 3(E)). Thus, PLGA scaffold with nanofibre of $100 \mathrm{~nm}$ diameter was used for subsequent experiment.

\section{IMMUNOGENICITY OF PLGA}

${ }^{3} \mathrm{H}-\mathrm{TdR}$ incorporation assay $(96 \mathrm{~h} / \mathrm{H})$ showed that exposure to PLGA does not induce PBMC proliferation. As shown in Figure 4(A), the incorporation of ${ }^{3} \mathrm{H}-\mathrm{TdR}$ in PBMC exposed with PLGA nanofibre scaffold (165.3 \pm 88.1$)$ was equivalent to unstimulated PBMC $(147.7 \pm 23.2)$ and those value was significantly lower compare to PHA induced PBMC (2382.7 \pm 1709.8$)$. Similarly, flow cytometric evaluation of CFSE intensity of CD3 T cells indicated no difference between cells cultured on PLGA and normal culture dish (Figure 4(B)-4(F)). Analysis of proliferation index based on CFSE intensity showed that PLGA does not stimulate $T$
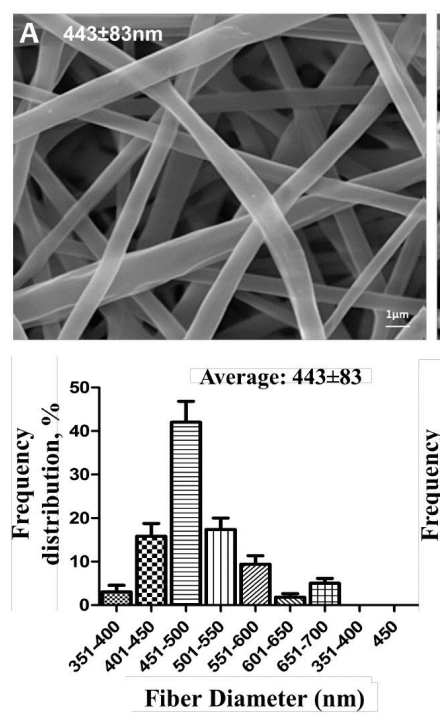

D

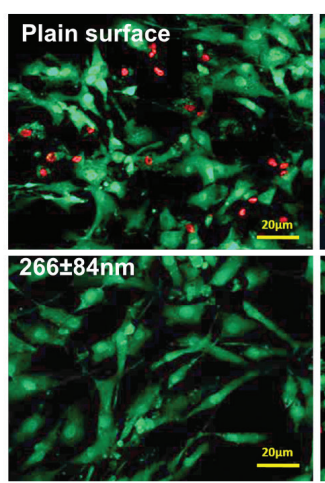

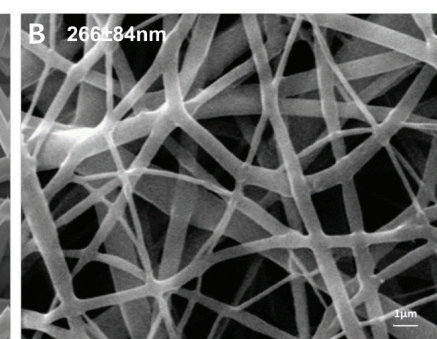

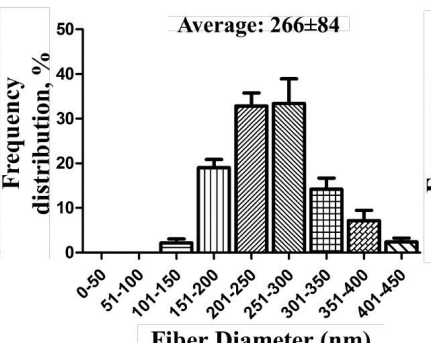

Fiber Diameter (nm)
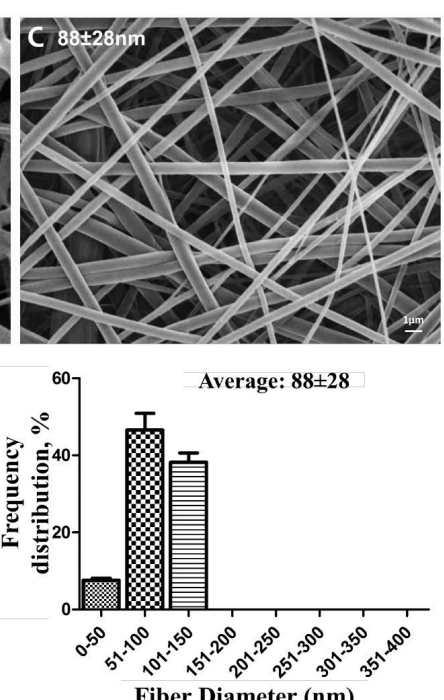

Fiber Diameter (nm)

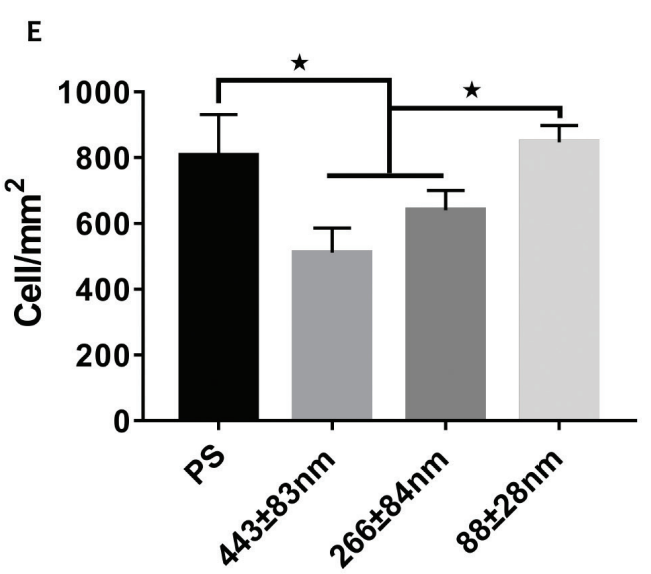

FIGURE 3. SEM images of fiber diameter and viability of OAC after cultured on the PLGA nanofibres: (A-C) SEM images with a different range of fiber diameter, (D) Fluorescence images of live OAC (green) and dead OAC (red) cultured on a plain surface, 100, 300 and $500 \mathrm{~nm}$. Scale bar $=20 \mu \mathrm{m}$, and (E) A number of OAC were calculated and more than 3 panels were processed and evaluated for each condition. ${ }^{*} p<0.05$; significant different 
A

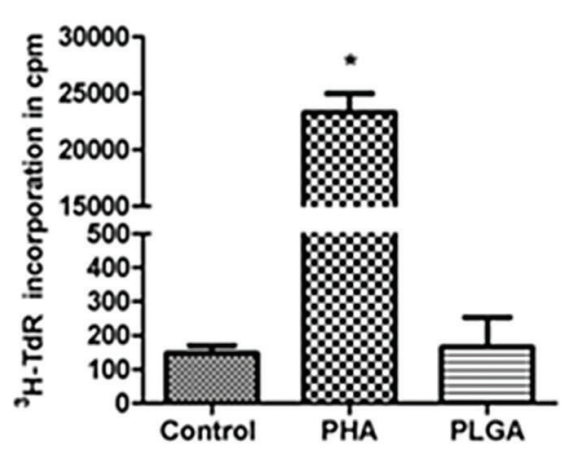

C
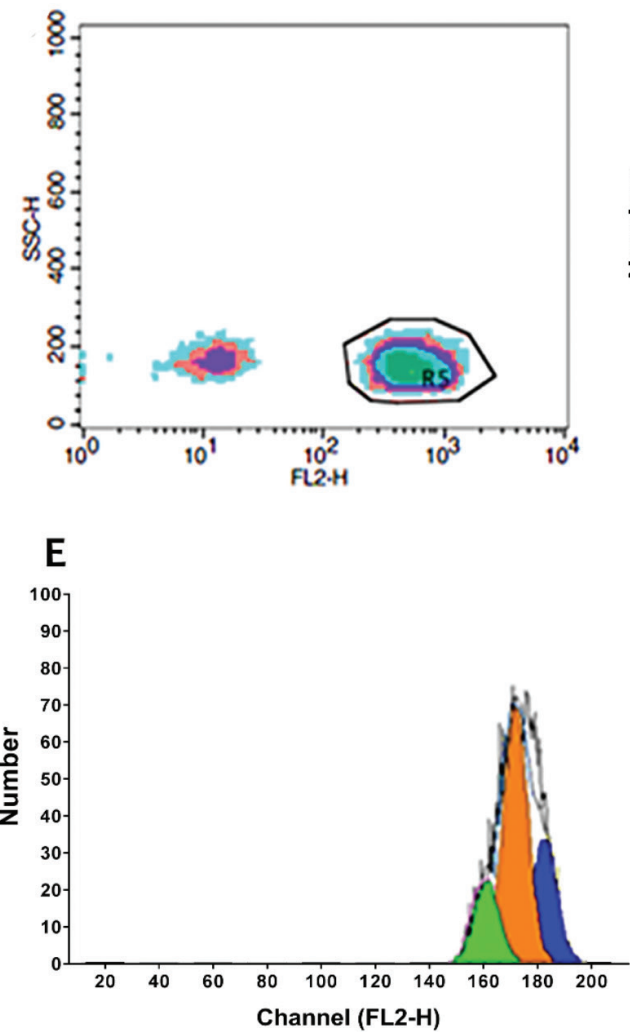

G

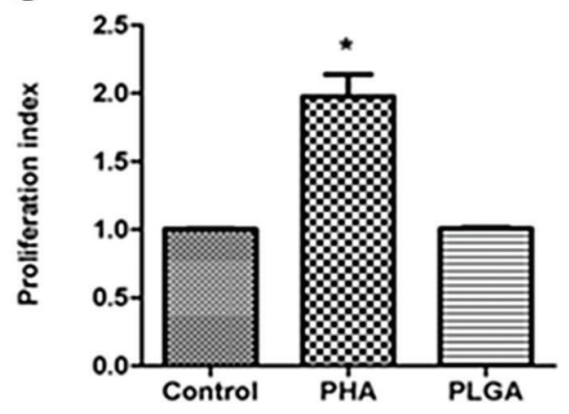

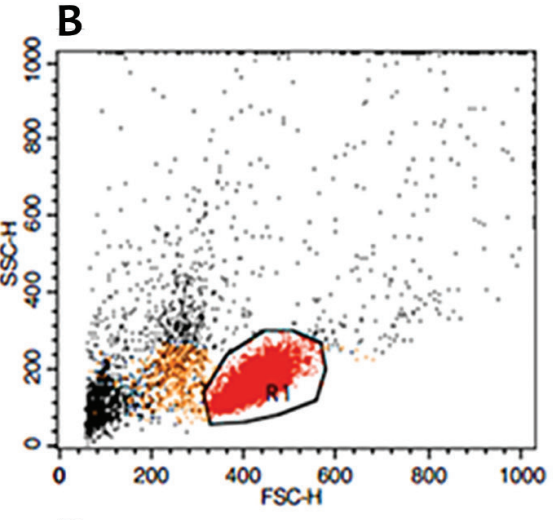

D

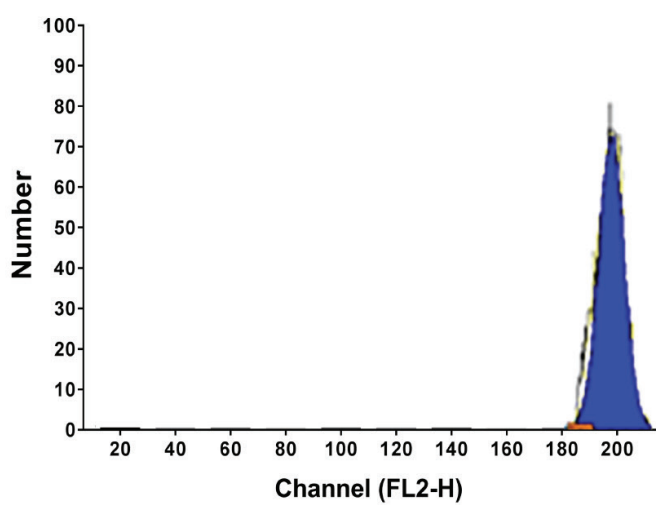

$\mathbf{F}$

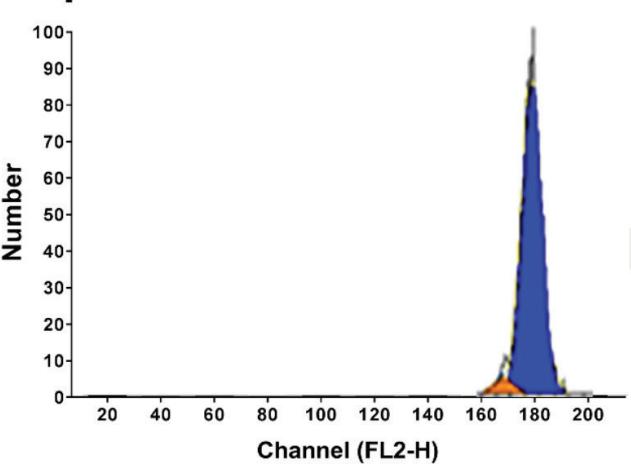

FIGURE 4. T-cell and PBMC proliferation upon PLGA scaffold: (A) PBMC proliferation was determined with ${ }^{3} \mathrm{H}-\mathrm{TdR}$ incorporation $96 \mathrm{~h}$ after stimulation with $1 \mu \mathrm{g} / \mathrm{mL}$ PHA, (B) Flow cytometry scatters plot showing PBMC distribution $96 \mathrm{~h}$ post stimulation, (C) Density plot showing CD3 sub-gating. CFSE intensity analyses are shown in D-F, (D) Unstimulated PBMC and (E) PBMC stimulated with $1 \mu \mathrm{g} / \mathrm{mL}$ PHA was used as negative and positive controls respectively, (F) PBMC cultured in presence of $2 \mathrm{~mm}$ discs of PLGA, and $(\mathrm{G})$ The bar chart shows mean \pm SD of proliferation index of T cells from three independent biological replicates. ${ }^{*} p<0.05$; compared to control $\left(\mathrm{CPM}\right.$, counts per $\mathrm{min} ;{ }^{3} \mathrm{H}-\mathrm{TdR}$, tritiated thymidine; PHA, polyhydroxyalkanoates; SD, standard deviation) 
cells to a division cycle (Figure $4(G)$ ). Taken together, these data demonstrate that PLGA does not provoke an immune response in vitro.

\section{GROWTH AND CHONDROGENIC PROPERTIES OF OAC ON PLGA NANOFIBRE SCAFFOLDS}

OAC behavior on PLGA nanofibres has been analyzed from day 1 until day 3 (24, 48 and $72 \mathrm{~h}$ ). The number of cells increases exponentially with culture time. At $24 \mathrm{~h}$, the number of cells on PLGA nanofibre scaffold was $281.7 \pm 111.5$ cells $/ \mathrm{mm}^{2}$, which increase to $464 \pm$ 87.03 cells $/ \mathrm{mm}^{2}$ at $72 \mathrm{~h}$ (Figure 5(A)). SEM micrographs shown that OAC started to attach on the fibers by $24 \mathrm{~h}$ and continue to elongate and flatten with formation of multiple pseudopodia. At $72 \mathrm{~h}$, the cells merged together and started to formed aggregation (Figure 5(B)). Immunofluorescence staining demonstrated the expression of type II collagen throughout the culture period, which increases gradually with increasing culture period (Figure 5(B)). Proteoglycan expression by $\mathrm{OAC}$ was also increase with culture time (Figure 5(C)). The expression of anabolic (sox 9, type II collagen, COMP and ACAN) and catabolic (MMP13 and ADAMTS5) markers by OAC was also evaluated and compared with cells cultured on monolayer, pellet and PLGA nanofibre scaffold (Figure 5(D)). It was found that the expression of anabolic markers, except for collagen type II, by OAC was significantly higher on PLGA nanofibre scaffolds compared to monolayer (Sox9; 4-fold, the ratio of type I/II collagen; 2-fold, COMP; 13-fold and ACAN; 2-fold). However, the expression of anabolic markers, except for COMP, was still higher in pellet culture compare to PLGA nanofibre scaffold, but no significant difference was observed. Meanwhile, the expression of catabolic markers was significantly higher in monolayer culture as compared to OAC culture on PLGA nanofibre scaffold and in pellet. Although the expression of catabolic markers is low in pellet culture compared to PLGA nanofibre scaffold, no significant difference was detected.

\section{DISCUSSION}

The purpose of this study was to demonstrate the regenerative potential of chondrocytes from OA cartilage (OAC) and evaluate the growth and chondrogenic properties of OAC on nanofibre scaffolds. It was shown that OAC expressed classic MSCs markers such as CD14, CD29, CD44, CD73, CD90 and were devoid of CD45 and HLA-DR. The OAC also exhibited potential to differentiate into the three main mesodermal lineages i.e. osteocyte, adipocyte, and chondrocyte. These results showed that OACs meets the minimum requirement to be categorized as MSCs, which included plastic adherence, high expression $(\geq 95 \%)$ of CD14, CD29, CD44, CD73, CD90, less ( $\geq 2 \%)$ CD45 and HLA-DR and potentially induced to osteocytes, adipocytes and chondrocytes (Hafez et al. 2016). Previous study also concluded a similar finding in adult human normal and OA cartilage. They used a combination of phenotypic and functional analyses to address this issue. The expression of CD105 and CD166 were found higher in both normal and OA cartilages. Interestingly, they showed that OA cartilage showed higher expression of CD105 and CD166 cells as compared to normal cartilage group (Alsalameh et al. 2004). The expression of progenitor cells from OA cartilage probably originated from proliferation of resident progenitor cells or from the environment itself.

Electrospinning is widely used due to its unique, simple and cost effective system. It can generate scaffolds with nanoscale topography, which mimics the structure of extracellular matrix, provide a higher surface to volume ratio and modulates the biological properties of various cell types. However, the mechanisms by which cells adapt and respond to nanoscale topography remain unclear and are worthy of investigation. PLGA nanofibres were chosen as the scaffold in this study because of its potential to tunable mechanical properties and degradation rate. A long lasting challenge with the culture of chondrocytes is the dedifferentiation of the cells, thus requiring culturing on 3D environment.

A few analyses were reported on identifying chondrocytes properties on 3D nanofibre scaffolds (Noriega et al. 2012; Sadeghi et al. 2016). It is also widely known that the chondrocytes might lose its properties when cultured in tissue culture plate. Consistently in the present study, OAC was found flattened and elongated as similar to the fibroblastic-like appearance that is also accompanied by a change in gene expression when cultured on tissue culture plate (Figure 5). As shown in Figure 5(B), OAC was noted to change in shape according to the matrix topography. Even though a non-rounded shape of cells was detected on the nanofibres at 24, 48 and $72 \mathrm{~h}$, the expression of type II collagen (Coll II) was not lost compared to control. The result was supported with the expression of sulphated matrix production (sGAG) (Figure 5(C)), which was gradually increased in regards to the culture duration. We presume that OAC was able to respond with their microenvironment, dedifferentiated on tissue culture plate after extracted from its natural ECM and redifferentiated back into a chondrocytes-like feature in 3D environment as similarly claimed by others elsewhere (Kino-oka et al. 2005). This suggested that the PLGA nanofibre scaffolds could support both cellular proliferation and differentiation.

Furthermore, analyses have shown that submicron size topography was of fundamental importance in maintaining chondrocytes specific gene (Noriega et al. 2012; Shin et al. 2006). ADAMTS5 and MMP13 are known to be involved in degradation of cartilage ECM components especially on SOX 9. Importantly, SOX 9 is essential for the ability of chondrocytes to produce cartilage matrix (Zhang et al. 2015). Inhibition of SOX 9 significantly suppressed Col II, COMP and ACAN production and increased the expression of ADAMTS5 and MMP13 as well. Consistently in the present study, anabolic (SOX 9, Col II, COMP and ACAN) and catabolic markers (ADAMTS5 and MMP13) showed a low and high gene expression, respectively, in 
A

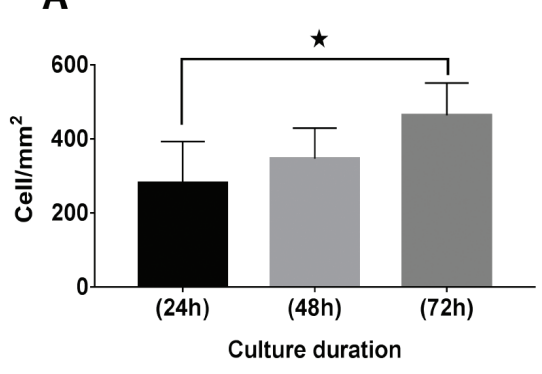

C SGAG analysis

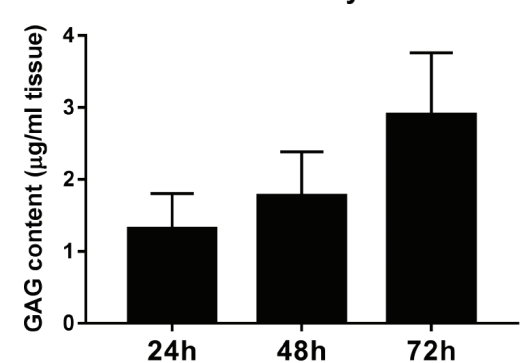

B
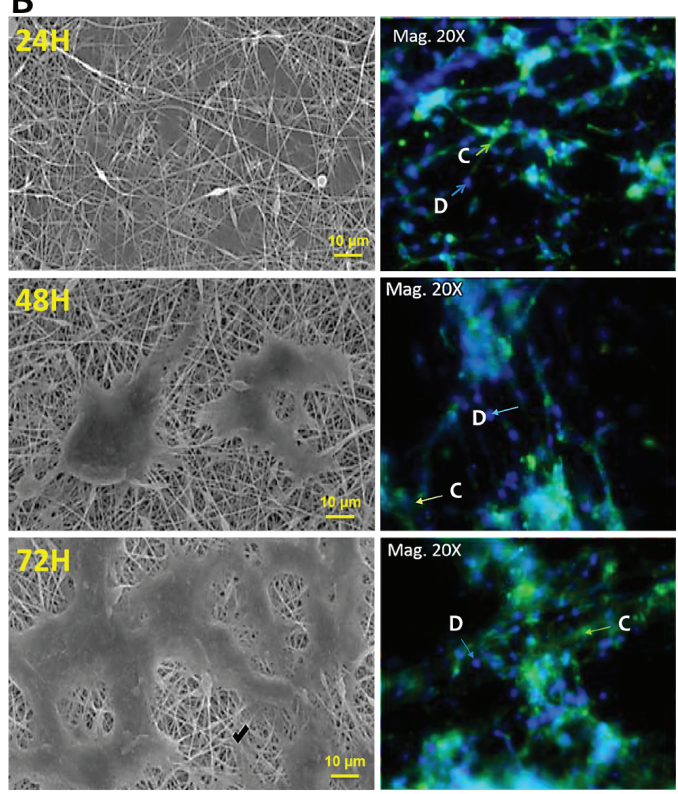

\section{D}
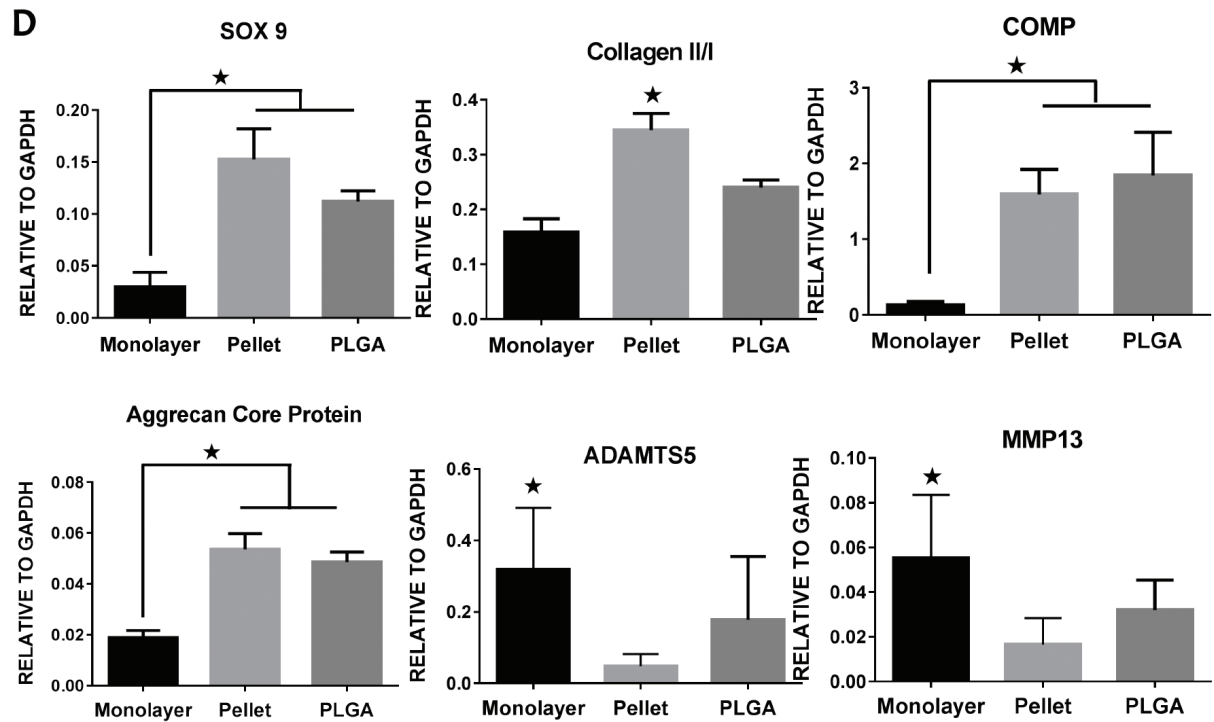

FIGURE 5. OAC behavior on PLGA nanofibres: (A) Number of cell increased relatives to culture duration $24 \mathrm{~h}=281.7 \pm 111.5$ cells $/ \mathrm{mm}^{2}, 48 \mathrm{~h}=346.8 \pm 82.19$ cells $/ \mathrm{mm}^{2}, 72 \mathrm{~h}=464 \pm 87.03 \mathrm{cells} / \mathrm{mm}^{2}$, (B) Proteoglycan deposition showed no significant differences between 24, 48 and $72 \mathrm{~h}$, (C) SEM images of OAC on nanofibre and the expression type II collagen deposition at 24, 48, $72 \mathrm{~h}$, (D) mRNA expression for anabolic markers (sox 9, type II collagen, COMP and ACAN) was increased in 3D structure (pellet and PLGA) compared to monolayer culture and catabolic markers (ADAMTS5 and MMP13) was decreased in 3D structure compared to monolayer culture at day 14 (OAC $n=5) . * p<0.05$; significant different

tissue culture plate (Figure 5(D)). We presume that the cells undergone dedifferentiation phase and accumulated more catabolic markers and reduced anabolic gene properties along the culture duration. However, when OAC was cultured in PLGA nanofibres it shows that the anabolic gene was up regulated while the catabolic markers were down regulated. It was comparably different than the gene expressed in tissue culture plate. We presume that PLGA nanofibres are able to redifferentiate the OAC into normal chondrocytes properties as similarly reported elsewhere (Fernandes et al. 2013). Even though nanofibres show better gene expression compared to tissue culture plate, the expression was still low when compared to a pellet culture however no significant difference was recorded. The pellet culture is a well-known method in forming a cartilage tissue (Anderson et al. 2016; Caron et al. 2012; Schrobback et al. 2011; Zhang et al. 2015). Comparing PLGA nanofibres with pellet culture provides better understanding on the efficiency and suitability of this fiber for future chondrocytes induction. We also believed that a pathogenic tissue like OAC still has the key value upon tissue reconstruction in the future. 


\section{CONCLUSION}

The present study found that although the source of the cell used was an abnormal cell (OAC), it had the potential to act as a normal cell after being cultured in an appropriate environment. In fact, OAC has high stem cell properties that almost resemble BMSCs for tissue regeneration. The interaction between OAC and PLGA nanofibre also shows that this microenvironment is able to control the structure and function of the cell during cultivation. Although some researchers have stated that PLGA is hydrophobic but, OAC was found to be able to interact well with the material. Thus providing further justifications for future indept research by producing PLGA nanofibre hybrid with other natural or synthetic polymers to ensure it is more suitable for the purpose of cell culture and regenerative tissue.

\section{ACKNOWLEDGEMENTS}

This work was funded by grants from Universiti Kebangsaan Malaysia (AP-2013-015) and the Malaysian Ministry of Science and Technology Science Fund (0201-02-SF0961).

\section{REFERENCES}

Al Faqeh, H., Nor Hamdan, B.M., Chen, H.C., Aminuddin, B.S. \& Ruszymah, B.H. 2012. The potential of intra-articular injection of chondrogenic-induced bone marrow stem cells to retard the progression of osteoarthritis in a sheep model. Experimental Gerontology 47(6): 458-464.

Alsalameh, S., Amin, R., Gemba, T. \& Lotz, M. 2004. Identification of mesenchymal progenitor cells in normal and osteoarthritic human articular cartilage. Arthritis and Rheumatism 50(5): 1522-1532.

Anderson, D., Markway, B.D., Bond, D., McCarthy, H.E. \& Johnstone, B. 2016. Responses to altered oxygen tension are distinct between human stem cells of high and low chondrogenic capacity. Osteoarthritis and Cartilage 24. Stem Cell Research \& Therapy: S164.

Caron, M.M., Emans, P.J., Coolsen, M.M., Voss, L., Surtel, D.A., Cremers, A., van Rhijn, L.W. \& Welting, T.J. 2012. Redifferentiation of dedifferentiated human articular chondrocytes: Comparison of $2 \mathrm{D}$ and $3 \mathrm{D}$ cultures. Osteoarthritis and Cartilage 20(10): 1170-1178.

Chua, K.H., Aminuddin, B.S., Fuzina, N.H. \& Ruszymah, B.H.I. 2005. Insulin-transferrin-selenium prevent human chondrocyte dedifferentiation and promote the formation of high quality tissue engineered human hyaline cartilage. European Cells and Materials 9: 58-67.

Darling, E.M. \& Kyriacos, A.A. 2003. Articular cartilage bioreactors and bioprocesses. Tissue Engineering 9(1): 9-26.

Dimida, S., Barca, A., Cancelli, N., de Benedictis, V., Raucci, M.G. \& Demitri, C. 2017. Effects of genipin concentration on cross-linked chitosan scaffolds for bone tissue engineering: Structural characterization and evidence of biocompatibility features. International Journal of Polymer Science 2017: 8410750

Dua, R., Comella, K., Butler, R., Castellanos, G., Brazille, B., Claude, A., Agarwal, A., Liao, J. \& Ramaswamy, S. 2016. Integration of stem cell to chondrocyte-derived cartilage matrix in healthy and osteoarthritic states in the presence of hydroxyapatite nanoparticles. Plos One 11(2): e0149121.

Fernandes, A.M., Herlofsen, S.R., Karlsen, T.A., Küchler, A.M., Fløisand, Y. \& Brinchmann, J.E. 2013. Similar properties of chondrocytes from osteoarthritis joints and mesenchymal stem cells from healthy donors for tissue engineering of articular cartilage. PLoS One 8(5): e62994.

Gentile, P., Chiono, V., Carmagnola, I. \& Hatton, P.V. 2014. An overview of poly(lactic-co-glycolic) acid (plga)-based biomaterials for bone tissue engineering. International Journal of Molecular Sciences 15(3): 3640-3659.

Hafez, P., Jose, S., Chowdhury, S.R., Ng, M.H., Ruszymah, B.H. \& Abdul Rahman Mohd, R. 2016. Cardiomyogenic differentiation of human sternal bone marrow mesenchymal stem cells using a combination of basic fibroblast growth factor and hydrocortisone. Cell Biology International 40(1): 55-64.

Hasmad, H.N., Yusof, M.R., Mohd Razi, Z.R., Haji Idrus, R.B. \& Chowdhury, S.R. 2018. Human amniotic membrane with aligned electrospun fiber as scaffold for aligned tissue regeneration. Tissue Engineering Part C: Methods 24(6): 368-378.

Jiang, Y. \& Tuan, R.S. 2015. Origin and function of cartilage stem/progenitor cells in osteoarthritis. Nature Reviews: Rheumatology 11(4): 206-212.

Khorsand-Ghayeni, M., Sadeghi, A., Nokhasteh, S. \& Molavi, A.M. 2016. Collagen modified PLGA nanofibers as wounddressing. Proceedings of the 6th International Conference on Nanostructures (ICNS6). March.

Kino-oka Masahiro, Yoshikatsu Maeda, Yuka Ota, Shino Yashiki, Katsura Sugawara, Takeyuki Yamamoto \& Masahito Taya. 2005. Process design of chondrocyte cultures with monolayer growth for cell expansion and subsequent three-dimensional growth for production of cultured cartilage. Journal of Bioscience and Bioengineering 100(1): 67-76.

Koh Yong Gon, Yun Jin Choi, Sae Kwang Kwon, Yong Sang Kim \& Jee Eun Yeo. 2015. Clinical results and second-look arthroscopic findings after treatment with adipose-derived stem cells for knee osteoarthritis. Knee Surgery, Sports Traumatology, Arthroscopy : Official Journal of the ESSKA 23(5): 1308-1316.

Félix Lanao, R.P., Jonker, A.M., Wolke, J.G.C., Jansen, J.A. van Hest, J.C.M. \& Leeuwenburgh, S.C.G. 2013. Physicochemical properties and applications of poly(lactic-co-glycolic acid) for use in bone regeneration. Tissue Engineering Part B: Reviews 19(4): 380-390.

Langer, R. \& Vacanti, J.P. 1993. Tissue engineering. Science 260(5110): 920-926.

Liu Mei, Xin Zeng, Chao Ma, Huan Yi, Zeeshan Ali, Xianbo Mou, Song Li, Yan Deng \& Nongyue He. 2017. Injectable hydrogels for cartilage and bone tissue engineering. Bone Research 5: 17014

Liu, S.J., Kau, Y.C., Chou, C.Y., Chen, J.K., Wu, R.C. \& Yeh, W.L. 2010. Electrospun PLGA/collagen nanofibrous membrane as early-stage wound dressing. Journal of Membrane Science 355(1-2): 53-59.

Madeira, C., Santhagunam, A., Salgueiro, J.B. \& Cabral, J.M.S. 2015. Advanced cell therapies for articular cartilage regeneration. Trends in Biotechnology 33(1): 35-42.

Mano, J.F., Sousa, R.A., Boesel, L.F., Neves, N.M. \& Reis, R.L. 2004. Bioinert, biodegradable and injectable polymeric matrix composites for hard tissue replacement: State of the art and recent developments. Composites Science and Technology 64(6): 789-817. 
Nazempour, A. \& Van Wie, B.J. 2016. Chondrocytes, mesenchymal stem cells, and their combination in articular cartilage regenerative medicine. Annals of Biomedical Engineering 44(5): 1325-1354.

Noriega, S.E., Hasanova, G.I., Schneider, M.J., Larsen, G.F. \& Subramanian, A. 2012. Effect of fiber diameter on the spreading, proliferation and differentiation of chondrocytes on electrospun chitosan matrices. Cells Tissues Organs 195(3): 207-221.

Oda, T., Sakai, T., Hiraiwa, H., Hamada, T., Ono, Y., Nakashima, M., Ishizuka, S., Matsukawa, T., Yamashita, S., Tsuchiya, S. \& Ishiguro, N. 2016. Osteoarthritis-derived chondrocytes are a potential source of multipotent progenitor cells for cartilage tissue engineering. Biochem. Biophys. Res. Commun. 479(3): 469-475.

Pak, J., Lee, J.H., Park, K.S., Jeong, B.C. \& Lee, S.H. 2016. Regeneration of cartilage in human knee osteoarthritis with autologous adipose tissue-derived stem cells and autologous extracellular matrix. BioResearch Open Access 5(1): 192-200.

Sadeghi, A.R., Nokhasteh, S., Molavi, A.M., Khorsand-Ghayeni, M., Naderi-Meshkin, H. \& Mahdizadeh, A. 2016. Surface modification of electrospun plga scaffold with collagen for bioengineered skin substitutes. Materials Science and Engineering C 66: 130-137.

Schrobback, K., Klein, T.J., Schuetz, M., Upton, Z., Leavesley, D.I. \& Malda, J. 2011. Adult human articular chondrocytes in a microcarrier-based culture system: Expansion and redifferentiation. Journal of Orthopaedic Research 29(4): 539-546.

Shin, H.J., Lee, C.H., Cho, I.H., Kim, Y-J., Lee, Y-J., Kim, I.A., Park, K-D., Yui, N. \& Shin, J-W. 2006. Electrospun PLGA nanofiber scaffolds for articular cartilage reconstruction: Mechanical stability, degradation and cellular responses under mechanical stimulation in vitro. Journal of Biomaterials Science: Polymer Edition 17(1): 103-119.

Thapa, A., Miller, D.C., Webster, T.J. \& Haberstroh, K.M. 2003. Nano-structured polymers enhance bladder smooth muscle cell function. Biomaterials 24(17): 2915-2926.

Ude, C.C., Shamsul, B.S., Ng, M.H., Chen, H.C., Ohnmar, H., Amaramalar, S.N., Rizal, A.R., Johan, A., Norhamdan, M.Y.,Azizi, M., Aminuddin, B.S. \& Ruszymah, B.H.I. 2018. Long-term evaluation of osteoarthritis sheep knee, treated with tgf- $\beta 3$ and bmp-6 induced multipotent stem cells. Exp. Gerontol. 104: 43-51.

Ude, C.C., Shamsul, B.S., Ng, M.H., Chen, H.C., Johan, A., Norhamdan, M.Y., Aminuddin, B.S. \& Ruszymah, B.H.I. 2014. Cartilage regeneration by chondrogenic induced adult stem cells in osteoarthritic sheep model. PloS One 9(6): e98770.
Wang, Y., Wu., S.H., Kuss, M.A., Streubel,P.N. \& Duan, B. 2017. Effects of hydroxyapatite and hypoxia on chondrogenesis and hypertrophy in $3 \mathrm{~d}$ bioprinted ADMSC laden constructs. ACS Biomaterials Science \& Engineering 3(5): 826-835.

Yoshimoto, H., Shin, Y.M., Terai, H. \& Vacanti, J.P. 2003. A biodegradable nanofiber scaffold by electrospinning and its potential for bone tissue engineering. Biomaterials 24(12): 2077-2082.

Zhang, Q., Ji, Q., Wang, X., Kang, L., Fu, Y., Yin, Y., Li, Z., Liu, Y., Xu, X. \& Wang, Y. 2015. SOX9 is a regulator of ADAMTSs-induced cartilage degeneration at the early stage of human osteoarthritis. Osteoarthritis and Cartilage 23(12): 2259-2268.

B.S. Shamsul \& S.R. Chowdhury*

Tissue Engineering Centre

Faculty of Medicine

Universiti Kebangsaan Malaysia

Clinical Block, Jalan Yaacob Latiff

56000 Cheras, Kuala Lumpur, Federal Territory

Malaysia

B.H.I. Ruszymah

Department of Physiology

Faculty of Medicine

niversiti Kebangsaan Malaysia

Pre-clinical Block, Jalan Yaacob Latif

56000 Cheras, Kuala Lumpur, Federal Territory

Malaysia

B.M.Y. Nor Hamdan

Department of Orthopedic \& Traumatology

Faculty of Medicine

Universiti Kebangsaan Malaysia

Clinical Block, Jalan Yaacob Latif

56000 Cheras, Kuala Lumpur, Federal Territory

Malaysia

*Corresponding author; email: shiplu@ppukm.ukm.edu.my

Received: 31 March 2018

Accepted: 5 June 2018 